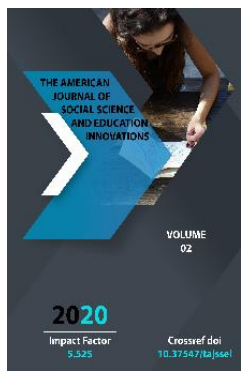

\title{
Democratic Principles Of State Governing Departments In Uzbekistan
}

\author{
Salieva Muhabbat Kushanovna \\ Candidate Of Philological Sciences, Independent Researcher Of The University Of Journalism \\ And Mass Communications Of Uzbekistan
}

Journal Website:

http://usajournalshub.c

om/index,php/tajssei

Copyright: Original

content from this work

may be used under the

terms of the creative

commons attributes

4.0 licence.

\section{ABSTRACT}

The article examines the processes of wide dissemination of socio-political, economic, spiritual aspects in the context of the development of modern state administration.

\section{KEYWORDS}

Democratic reforms, law, ideology, basic principles, concept, initiative, trend, analysis, instruction, definition, form, image, reform.

\section{INTRODUCTION}

Modern ideas about democracy correspond to the following general features. First is the recognition of the people as the source of power, the sovereignty of the state. Second, the main bodies of state power are the equality of voters, citizens and, above all, the equality of their suffrage. Third is the subordination of the minority to the majority in decision-making. For example, in a democratically organized state, power is exercised through special institutions. Thus, the various branches of government consist of: the legislature, the executive, and the administrative courts. 
The separation of powers is one of the basic principles of a democratic state. Its implementation will help prevent abuses and the emergence of authoritarian, absolute power unrelated to the law. The branches of government should not be united in the hands of a single body. The difference is designed to protect against the abuse of state power. No body has full state power. It does not allow another body to perform its respective functions. All bodies and branches of government are called upon to be the patrons of the Constitution. The division of powers is represented in the distribution of competencies, in the system of mutual control, control and balance, in the process of regulating and coordinating the balance.

At the new stage of our national development, large-scale, radical democratic reforms are being carried out in all spheres and spheres of society, and special attention is being paid to the development of the national economy and social sphere. Therefore, the President of the Republic of Uzbekistan Sh.M. Mirziyoyev's book, «The Constitution is a Free and Prosperous Life, a Strong Foundation for the Further Development of Our Country,» puts forward the principle that «we must all deeply understand the essence of the constitutional principle of people's power» $[1$, -P.29].

To do this, it is necessary to widely introduce the practice of reporting to the people's representatives - parliament and local councils - at various levels of the executive branch. We need to further develop parliamentary, representative and public oversight mechanisms. Every public servant should never forget that he is accountable to the people. At the same time, ensuring the transparency of government agencies is an integral part of implementing this principle in practice. It is based on the principle that the government need to create all the conditions for our people to know what government agencies, as well as their elected representatives, are doing, to be able to objectively assess their activities. [2, -P.30].

The main goal is to create legal communication in the democratic principles of government, which takes into account the legal technical process, that is, legal technology - on the one hand, it is citizens, social groups, and civil society in general. The state, on the other hand, is a collection of methods and techniques provided by its legislative and law enforcement agencies.

In civil society, public authorities and administration bodies perform only the most important functions in the national interest. These include defense, national security, foreign policy, the formation of the monetary and tax system, the development of legislation. In particular, today these norms are included in the legal system of the Republic of Uzbekistan.

When we look at the activities of all levels of government, do they serve the goals we have set for ourselves; are they able to exercise their powers in further democratization and further development of our society? It is important to find answers to these questions. However, it is no secret that the more ineffective the links of governance, the greater the difficulties and obstacles to the development of civil society.

Our work must be focused on the most important constitutional rule - the implementation of the principle of social justice. 
Social justice is about ensuring the equality of all citizens before the law, regardless of their political views, gender, nationality, language and religious beliefs. This is equality of opportunity in education, medicine and other areas. This is guaranteed freedom of labor, equal opportunities for positions. Most importantly, it is about caring for the older generation and citizens in need of social protection. Our main task in deciding the principle of social justice in society is the adoption of fair laws [3, -P.31].

It should be noted that the style of lawmaking plays an important role in the rule of law and in the process of its adoption, and therefore represents a space of special attention. In the process of forming a legal text, it is important to strive for clarity in the use of the rules of legal technology, as this increases the reliability of legal norms and the ability to understand them. Respect and observance of the law is the main goal of legal communication, public propaganda.

If the law is fair, if it protects human rights in practice, then people will respect and obey the law [4, -P.31].

The introduction and explanation of good governance is a legal advocacy procedure.

In the development of democratic principles of state power, it is important to understand not only the existence of laws, but also their content and significance, the dissemination of this information to the public.

Ensuring the constitutional rights of citizens to freedom of thought, speech and religion is an important condition for building a developed democratic state and a strong civil society [5, -P.31]. It should not be based on the use of physical force in the first place. The leading task of the legal system is to explain the legal norms to the public, that is, to implement effective mass legal communication. The law must first and foremost have spiritual, moral force.

In today's era of democratic change, we must ensure that the full potential of our citizens who want to participate directly and actively in the political and social life of our country is fully manifested. In this regard, it is important to consider the concept of a multi-party system, inter-party debate, the rapid development of competition between ideas and programs.

The media must become an important and effective means of conveying the demands and needs of the population to the authorities, the closest supporter of the people, the mirror of democracy. Critical and objective assessment of the activities of government and administration, shortcomings in various areas, bold raising of current issues should be the main criteria in their activities [6, -P.31]. Apparently, the head of state will gradually implement legal advocacy and apply a free communication regime, which is the most powerful tool for strengthening the legal system. Examples of this are today's Presidential Reception, offices that listen to the people's concerns in the form of open dialogues.

Another important task of ours is the consistent implementation of the principle of interdependence of rights, duties and responsibilities between citizens, the state and society [7, -P.31]. Such legal concepts are legal communication that takes place directly in public.

This principle is the constitutional basis that ensures effective cooperation between the 
state and the individual, the state and civil society in addressing the important tasks facing our country.

While the laws protect the rights of citizens, they ensure that they are fair to each other. In return, society needs strong laws.

The Constitution of Uzbekistan is rightly called effective, and its role in the Basic and Supreme Law of the country is its main influence $[8,-$ P.30].

As long as the laws are perfectly drafted, it will be possible to fully organize the life of the state and society only if they are well promoted.

The creation of human rights legislation is not only a condition of the transition period, but also a characteristic feature of building a democratic state governed by the rule of law. The formation of human rights laws in accordance with international standards is a long and continuous process [9, -P.49].

The existing legal framework for the renewal and further democratization of public administration in Uzbekistan, as well as the strengthening of the participation of political parties in the modernization of the country, is gradually being improved. Such updating of the legal framework requires amendments to the Constitution of the Republic of Uzbekistan, as well as amendments and additions to existing legislation. Law scholar A.H.Shodmonov in his book "The Development of Civil Society in Uzbekistan", he writes: In the relationship between man and the state, human interests take precedence, and the foundations of all branches of state and state power are mobilized to protect and safeguard human rights [10, -B.11], when laws are created in the public interest if compliance is ensured, a legal culture will be formed among the general public. To do this, during the election of people's deputies, first of all, the people must be elected in a democratic way, from the people, enthusiastic, educated candidates, in a highly fair manner.

As a result of the development of modern innovative technologies in proportion to the demands of the times, reforms determine the interests of man, a decent lifestyle. It is noteworthy that as a priority of political reforms in the country, first of all, serious attention is paid to improving the activities of public administration, the constitutional strengthening of their powers.

It is noteworthy that in a democratic society, the work on strengthening the multiparty system, radical reform of public and nongovernmental organizations, the media, and self-government bodies has been carried out.

It is noted in the "Concept of further deepening democratic reforms and development of civil society in the country" put forward by the President, it is said that the feeling of pride of country's economic and social achievements, global financial and economic achievements and detachment from reality can have a negative impact on the development of the country.

At the same time, the growing political and legal culture and social consciousness of the population, the rapid development of democratization and liberalization of society, the strengthening of the multiparty system in our country have further strengthened the powers between the three branches of government, the President, the legislature and the executive institution which has been 
requiring the creation of the necessary conditions to ensure a balanced distribution.

In the life of society, along with the legal culture in the minds of citizens, it is possible to see that their political culture, their participation in the management of the state and society is becoming more active, their sense of involvement in the political process is growing.

Democratic principles of state power and administration, changes in the scope of their powers, the importance of legal communication in the process of democratization of state power and administration in the distribution of power in the country will be extremely effective.

The issue of democratization of modern public administration was first highlighted in 2010 at a joint session of the Legislative Chamber and the Senate of the Oliy Majlis of the Republic of Uzbekistan as the first priority of the report "Concept of further deepening democratic reforms and development of civil society." This opened a new era, a number of legislative ideas aimed at enhancing the role of political parties in the further development and strengthening of public authorities, in particular the parliament, the judicial system, electoral legislation, the development of civil society institutions, the media, deepening democratic reforms and economic liberalization will be based on the initiated democratic principle

During the past period, reforms in the field of democratization of state power and governance had a very important purpose, in other words, they were aimed at taking crucially essential measures towards the implementation of the constitutional principle of separation of powers, the formation of an effective system of checks and balances between powers, liberalization of the judiciary and ensuring its independence, strengthening the role of legislative and representative powers at the center and at the local level[11].

In the new period of development of Uzbekistan, along with the liberalization of the political sphere, the main focus in state building and the formation of civil society will be on the following issues: ensuring the independent functioning of all branches of government; non-governmental and public organizations, gradual liberalization of civil society. The concept of "From a strong state to a strong civil society" is defined.

1. Liberalization of all spheres of political life, state and society building;

2. Ensuring a multi-party environment;

3. Establishment of non-governmental organizations and civil society;

4. Achievement of opinion diversity. Literal promotion of the mass media to the level of "fourth government";

5. It has been shown that human rights and freedoms consist of issues such as the establishment of democratic values in the minds of the people.

Ensuring the constitutional separation of powers in the field of state building and management; the goals are to increase the effectiveness of reforms in the administrative sphere, as well as to improve the system of selection, placement and renewal of personnel. The main task of the legal communication system is to apply the essence of the general policy to the life of society.

The result of innovative ideas is the harmonization of the powers of the central executive bodies and administrative bodies with market principles and, ultimately, a 
significant reduction in their role in the management of the state economy.

The self-governing bodies of the country as the main institution of civil society are improving year by year. Also, with the expansion of the scale of these bodies in the system of governance, there are favorable and wide opportunities for the rule of law to exercise its powers on the basis of democratic principles.

By the time of independence, serious reforms have been carried out to strengthen the legal status of local self-government bodies and make them the main institution of civil society. In the country, town, village, aul and mahalla citizens' assemblies have received the legal status of self-governing bodies. In particular, the Mahalla was re-established as an independent organization, and many of them regained their old names and prestige among the people.

It should be noted that the democratic principles of local self-government:

1. The principle of democracy, transparency, diversity of opinion.

2. The principle of inheritance.

3. Democratization of social relations.

4. The principle of high spirituality.

5. The principle of neighborhood security.

6. The principle of a sense of responsibility of the chairman (elder) and advisers of the citizens' assembly.

7. The principle of social protection, social justice, social security (community and mutual assistance).

8. The principle of council, consultation.

9. Humanism.

10. Independence.

As a result of public administration reforms, the role of the mahalla institute is growing. In order to further enhance the role of mahallas as self-governing bodies, to strengthen their role and importance, many decrees and decisions are being adopted by the head of state and the government.

In Uzbekistan, the institution of mahalla of a specific nature is a collective structure based on unique national values and traditions, which is not found in other countries, that is, mahalla management is closely linked with public authorities.

The democratic principle of modern state power is based on the creative use of the experience of developed democracies around the world, taking into account the specifics of the existing conditions. Accordingly, the executive branch is a branch of the system of state power.

Ensuring conditions for the implementation of laws is the main task of the executive bodies. According to the principle of separation of powers, the executive power, i.e. the government of the country, is vested in the Cabinet of Ministers. The Cabinet of Ministers consists of the Prime Minister, his deputies, ministers, and chairmen of state committees. The head of the government of the Republic of Karakalpakstan is an ex officio member of the Cabinet of Ministers.

The second part of Article 102 is worded as follows: "The governor of the region and the city of Tashkent shall be appointed and dismissed by the President of the Republic of Uzbekistan in accordance with the law." This law came into force on January 1, 2008. The termination of the post of Chairman of the Cabinet of Ministers of the Republic of Uzbekistan as the President of the Republic of Uzbekistan was also an important step towards liberalization and democratization. 
The institution of the presidency has been formed in the country, further improved, and its legal framework has been strengthened. As a result, Article 96 of the Constitution of the Republic of Uzbekistan deals with proposals and ideas on democratization of state power and administration, further liberalization of the institution of the presidency, the transition to a system of governance from the one in power into developed countries.

Typically, the executive branch is formed at least one month after the parliamentary elections.

The system of executive bodies includes the head of the Cabinet of Ministers, the Prime Minister, and heads of government ministries, state committees, and governors of regions, districts and cities, departments and administrations under their leadership, as well as the administration of enterprises, organizations and institutions in their system.

The executive bodies, on the basis of collective leadership and individually through the adoption of legal documents, develop and implement measures for the management and development of relevant areas. The system, legal status and powers of the executive branch are determined by the Oliy Majlis in accordance with the Constitution. Mass legal communication activities play an important role in these processes.

Over the past period, the legal framework for the consistent implementation of the constitutional principle of separation of powers, the creation of an effective system of checks and balances between the authorities has been adopted. The system of legal communication plays a special role in studying the significance of the Constitutional Law of the Republic of Uzbekistan "On modernization and further democratization of public administration and strengthening the role of political parties in modernizing the country."

This constitutional law regulates the organization of the Legislative Chamber and the Senate of the Oliy Majlis of the Republic of Uzbekistan, procedures for appointment and dismissal of the Prime Minister of the Republic of Uzbekistan, appointment and approval of candidates for regional and Tashkent city governors, and control over the activities of regional and Tashkent city governors embodied norms for strengthening the role of political parties in matters of oversight. An important aspect of legal communication in the development of the concept of democratic principles of state power is extremely important, and as an example, the compatibility of the law "On transparency of public administration" is particularly noteworthy.

Liberalization of the political life of the society requires, first of all, the strengthening of the political activity of the population, the gradual transfer of power to non-governmental and public organizations, citizens' self-government bodies.

The task of further liberalization of the economy will improve the expansion of economic freedoms of business entities, strengthening the status and rights of owners.

In order to further raise the morale of the society, it is important to bring up free, wellrounded people who recognize their rights, think independently, have strong faith and beliefs, combine their personal interests with the interests of the country and the people. 
Building a legal, democratic state and a free civil society requires the implementation of the National Training Program, the training of mature professionals who will ensure the future of the country.

Stronger social protection of the population is an important criterion for all stages of socioeconomic reforms in the country, in line with the content and essence of the "Uzbek model".

Ensuring structural changes in the economy, development of market infrastructure at this stage of economic reforms, increasing the production capacity of export-oriented and import-substituting products, improving the functioning of the financial and banking system are important.

\section{CONCLUSION}

In conclusion, one of the urgent tasks at this stage is to ensure stability in society, peace, interethnic and inter-citizen harmony, territorial integrity of our country. This task requires the creation of security systems that respond appropriately to threats that may threaten the sovereignty and sustainable development of Uzbekistan in the context of globalization and the aggravation of the situation in various regions.

The main task of legal communication is to participate in the implementation of the concept of improving the system of legal services in the development of democratic principles of state power in the Republic of Uzbekistan. It is to promote the effective implementation of a fair system.

\section{REFERENCES}

1. Sh.M. Mirziyoyev. Constitution - Erkin va farovon Haotimiz, Mamlakatimizni Yanada Taraққiу Ettirishning Mustaxkam Poidevoridir. $\quad-\mathrm{T} \quad$ : Uzbekiston. 2018. -P. 29.

2. Sh.M. Mirziyoyev. Constitution - Erkin va farovon Haotimiz, Mamlakatimizni Yanada Taraққіу Ettirishning Mustaxkam Poidevoridir. $-\mathrm{T} \quad$ : Uzbekiston. 2018. -P.30.

3. Sh.M. Mirziyoyev. Constitution - Erkin va farovon Haotimiz, mamlakatimizni yanada taraққiу ettirishning mustaxkam poidevoridir. $-\mathrm{T} \quad$. : Uzbekiston. 2018. -P. 31.

4. Sh.M. Mirziyoyev. Constitution - Erkin va farovon Haotimiz, Mamlakatimizni Yanada Taraққіу Ettirishning Mustaxkam Poidevoridir. $-\mathrm{T} \quad$. Uzbekiston. 2018. -P. 31.

5. Sh.M. Mirziyoyev. Constitution - Erkin va farovon Haotimiz, mamlakatimizni yanada taraққiу ettirishning mustaxkam poidevoridir. $-\mathrm{T} \quad$.: Uzbekiston. 2018. -P. 31.

6. Sh.M. Mirziyoyev. Constitution - Erkin va farovon Haotimiz, Mamlakatimizni Yanada Tаrаққіу Ettirishning Mustaxkam Poidevoridir. $\quad-T$ : Uzbekiston. 2018. -P. 31.

7. Sh.M. Mirziyoyev. Constitution - Erkin va farovon Haotimiz, Mamlakatimizni Yanada Taraққiу Ettirishning Mustaxkam Poidevoridir. $\quad-\mathrm{T} \quad \therefore$ Uzbekiston. 2018. -P. 31.

8. A.Kh. Saidov. Constitution of the Republic of Uzbekistan: A Proven Basis for Independent Development. T .: Uzbekistan. 2012. -P. thirty.

9. A.Kh. Saidov. Constitution of the Republic of Uzbekistan: A Proven Basis for Independent Development. T .: Uzbekistan. 2012. -P. 49. 
10. A.Kh.Shodmonov. Y̌zbekistonda Fuқarolik zhamiyatining rivozhlanishi. -T .: Uzbekiston, 2011. -B.11.

11. Mamlakatimizda democrat islyotlarni yanada chuқurlashtirish va fuқarolik zhamiyatini rivozhlantirish conceptions // Halқ sy̆zi, 2010 yil 13 November, no. 220 (5135). 